DOI: 10.20472/EFC.2019.011.008

\author{
BOŽENA KADEŘÁBKOVÁ \\ University of economics in Prague, Czech Republic
}

EMÍLIE JAŠOVÁ

Institute for Forcast, Czech Republic

\title{
THE RELATION BETWEEN MINIMUM WAGE AND UNEMPLOYMENT ACROSS THE ECONOMIC CYCLE IN COUNTRIES OF THE VISEGRAD GROUP
}

\begin{abstract}
:
The aim of the present article is to clarify existence and nature of the relation between minimum wage and selected unemployment indicators in countries of the Visegrad group, with the use of an empirical analysis. The obtained figures of correlation coefficients related to the Czech Republic, Hungary and Poland showed that the positive influence was predominant over the negative one, meaning rise of the minimum wage was followed by unemployment growth. In accordance with similar studies in the world we have proved that a contradictory effect of the relationship between minimum wage changes and selected unemployment indicators was also relevant for $\mathrm{V} 4$ countries.
\end{abstract}

\section{Keywords:}

Minimum wage, unemployment, unemployment rate, previous occupations of the unemployed, correlation coefficient

JEL Classification: E24, E32, E37 


\section{Introduction}

To a large extent, dynamics of economic performance of a country depend on flexibility of the labour market. Labour markets that are rigid or little flexible lead to growth of unemployment and social spending, they extend the phases of recessions and weak growth. The flexibility of labour market can be enhanced by well-designed institutional factors. However, among economists and politicians there are both supporters and opponents of regulations - and not only those related to the labour market.

One of the institutional factors that influence flexibility of the labour market is legislative protection of employment. Besides temporary employment, this institutional factor also includes minimum wage, payment for work overtime and mandatory non-wage benefits. Supporters of minimum wage regulation believe, that a higher minimum wage reduces unemployment and improves living standard of low-income groups. A higher minimum wage also makes the unemployed more willing to look for a job and to leave the welfare system of the state. On the other hand, opponents of the minimum wage regulation say that a high minimum wage pushes the employed out of the labour market and decreases chances of the unemployed to find a job.

The aim of this article and the empirical analysis is to assess the existence and nature of the relation between minimum wage and unemployment, with a focus on selected unemployment indicators in countries of the Visegrad group (V4). The first part provides an overview of results of international empiric analyses that were carried out either to confirm or to disprove the influence of minimum wage on employment, or rather unemployment. The second part provides details on sources of data and the method of analysis. In the third part, empirical testing of the relation between minimum wage and unemployment in V4 countries was carried out. The last part summarizes conclusions of the analysis.

\section{Comparison of International Analyses of Minimum Wage Influence on Unemployment}

A study that has become a classic is Blanchard and Wolfers's work (1999). The authors came to a conclusion that the composition of unemployment is influenced by labour market institutions. Ederveen and Thissen (2004) say that low-skilled employees, who receive wages that are higher than their productivity, are too expensive for employers.

Betcherman et al. (2001) claim that high minimum wage increases living standard and that its growth increases incomes of workers. Obadić et al. (2014) used fixed and random effects of panel models for the period from 2000 to 2011 and tested influence of taxes, social security contributions and institutions on the labour market. On the other hand, Aksentievič and Bogovič (2003) compared values of wages and living standard in Croatia and they found that wages were not the main factor of income inequality.

According to Čok et al. (2009) regulations on the labour market have a lot of adverse consequences, e.g. they hold back the process of jobs creation. However, authors Machin and Manning (1994) estimated that a decrease of minimum wage regulation by the Wages Council increased inequality of wages and did not lead to an increase in employment. Warren and Hamrock (2010) have proved that a higher minimum wage weakens the relation between unemployment rate and rate of university graduation.

Betcherman et al. (2001) found that a growth of minimum wage leads to a decrease in the number of vacancies with minimum wages. An interesting study by Orrenius and Závodný (2008) 
shows that the growth of minimum wage has a larger impact on low-skilled immigrants then on home state workers. Yuen (2003) says that changes of minimum wage have a large negative impact on employees with low wages.

A very interesting study was carried out by Hirsch et al. (2011). These authors think that the scope of the change of the minimum wage has an insignificant impact on employment, as the increase in other expenses is much more important for employers. Manning (2012) has come with an interesting suggestion to create an alternative of minimum wage in the form of a 'minimum wage for senior workers' (e.g. 30 years and older).

According to Jašová et al. (2016), regression models verified by the actual development of the real economy suggest a very weak adverse impact of the minimum wage indicator on structural unemployment in the V4 countries.

Dube et al. (2010) detected a strong influence of minimum wage on incomes, but no effects on employment in the USA. Metcalf (2007) says that an adverse effect of minimum wage on employment has not been proved. Cotterill and Wadycki (1976) found that employees received higher wages in subsectors that were more influenced by the federal and state minimum wage.

\section{Description of sources of data and methods of analysis}

The impact of minimum wage on unemployment, its nature and scope in individual V4 countries was studied using the minimum wage time series, which is expressed by the purchasing power parity - hereinafter PPP (Eurostat, 2015).

The development of variously classified unemployment was studied based on data from Eurostat $(2015)^{1}$. The time series used have an annual frequency and provide information for the period from the year 2000 to the year 2014. Before applying the correlation analysis, year-on-year changes were calculated from the original time series. The impact of minimum wage on unemployment is examined using the correlation analysis. In the text we distinguish between a positive and a negative value of correlation and unproved correlation. The strength of the mutual relation is expressed by the intensity of dependence. If the correlation coefficient equals to +1 , there is a functional direct linear dependence between the variables. If the value is -1 , there is an indirect functional linear dependence between the variables. If the characteristics of intensity (closeness) of dependence equal to 0 , there is a linear independence of the variables between the variables. The closer is the correlation coefficient in the absolute value to one, the stronger is the dependence. And the closer it is to zero, the weaker is the dependence.

A positive value of correlation of minimum wage and unemployment means that when the minimum wage grows, unemployment grows as well. A negative value of correlation means that when the minimum wage grows, unemployment declines. The more factors besides the minimum wage affect unemployment, the weaker is the influence proved between the two variables. Correlation coefficients in the interval from 0.00 to 0.05 in our analysis suggest that correlation between minimum wage and unemployment was not proved, the interval from 0.06 to 0.34 it shows a very weak correlation, the interval from 0.35 to 0.49 indicates weak correlation between the studied variables, the interval from 0.50 to 0.74 shows a medium correlation, the interval from 0.75 to 0.89 localizes a strong correlation and the interval from 0.90 to 1.00 signalizes a very strong correlation between the minimum wage and the selected unemployment indicator.

\footnotetext{
${ }^{1}$ According the Labour Force Sample Survey and the international ILO methodology.
} 
The results obtained by empirical testing of V4 countries data were compared with studies that used more sophisticated instruments (e.g. regression analysis, Granger causality, ARMA model, Differences in Differences method and regression analysis on panel data) and longer time series. We consider the results of this analysis to be rather indicative.

\section{Overview of results obtained by empirical testing of the relation between minimum wage and unemployment based on V4 countries data}

In order to make the issue of the impact of minimum wage changes on selected indicators clearer, we divided the results of the analysis into three groups for each country.

A. Positive values of the correlation coefficient suggest that the minimum wage and unemployment variables move in the same direction, which means that if the minimum wage grows, unemployment grows as well. The same applies to the other V4 countries as well.

The analysis shows that in case of the Czech Republic, the impact of changes of minimum wage on the overall unemployment rate of people between 50 and 54 is very weak, but it is positive. When there is a year-on-year growth of the minimum wage, those who are pushed out of the labour market are also women at the age of 50 to 64; we assess the correlation as very weak. When we took into account the educational attainment we found that there was a weak positive correlation in total and for men with lower than elementary, elementary and secondary education at the age of 35-39. As for the rate of young people neither in employment nor in education and training, a change of the minimum wage caused a weak reaction of the age group of 25-29. There was a weak positive value of correlation of the minimum wage proved for unemployed and inactive women at the age of 25-29.

As for the indicator number of people unemployed by the duration of unemployment, we detected a moderately strong positive correlation for unemployment lasting for 48 months and more at the age categories of 15-39 and 40-64. The same value of correlation showed for unemployment lasting for 48 months and more at the age category of 15 to 74 . As for the indicator overall longterm unemployment, there was a moderately strong positive correlation of the minimum wage for women at the age group of 25-29 and a weak correlation for women at the age of 40-44. When we took into account ways of registration and payment of benefits, we found that in the age group of 15-24 there was a weak positive correlation for the indicator registered unemployment without payment of benefits for unemployment lasting for 12-17 months. There was a moderately strong positive correlation for men at the age group of 15-39 who were unemployed for 3-5 months.

When we took into account the number of the unemployed according to individual professions, we found a very weak positive correlation for women working in services and trade. As for the rate of unemployment by regions, we proved a very weak positive correlation for women aged 20-64 in the Northwest region. A very weak positive correlation with the minimum wage was found for the number of unemployed women by regions indicator for the Northwest region (25 years old and older). The long-term unemployment rate by regions indicator suggested a weak positive correlation with the minimum wage in the Southeast region and a very weak positive correlation in the Southwest region.

B. Negative values of the correlation coefficient suggest that the minimum wage and unemployment variables move in an opposite direction, which means that when the minimum wage grows, unemployment declines. The same applies for other V4 countries.

The empirical analysis showed there was a negative value of the correlation coefficient in the Czech Republic, which means that according to the selected indicators, the change of the 
minimum wage led to a decline of unemployment. In accordance with conclusions of the Office of the Government of the Czech Republic, our analysis showed a negative impact of the minimum wage growth on unemployment of men1, where there was a very weak negative value of correlation proved for the age group of 30-34. Taking into account educational attainment, in total and for men there was also a very weak negative value of correlation proved between the minimum wage and the unemployment rate of workers with higher education at the age of 25 to 49. The comprehensive indicator young people neither in employment nor in education and training rate showed a rise of the minimum wage caused a very weak negative reaction, which means it led to a decrease in unemployment. The same applied to the indicator of the unemployed and inactive people aged 20-24. As for women, we assess the relation as weak and negative in relation to the unemployed and those who want to work aged 15-19. There was also a very weak negative correlation found for unemployed and inactive people aged 18 to 24 . The analysis also showed a very weak negative value of correlation for unemployed men aged 20 to 24 and for inactive people at the age group 20-34 and for people who do not look for a job aged 25-29.

Having assessed negative values of correlation between the minimum wage and unemployment according to the way of registration and benefit payment indicator, we found that there was a weak negative correlation for women and for the registered unemployment without benefits payment indicator when the unemployment lasted for 3-5 and the unemployed were 15 to 74 years old. As for men, the same indicator implied the same impact if the duration of unemployment was 24-47 months. Using the number of the unemployed according to the type of employment sought indicator, we found a weak negative reaction on the minimum wage changes for the unemployed aged 15 to 19, who used to work on a full-time or part-time basis. For women aged 15 to 24 there was a weak negative correlation regardless whether they used to work fulltime or part-time. When we had a look at the number of the unemployed according to individual professions, we found a very weak negative correlation for skilled workers. As for men, a very weak negative correlation was found for technicians.

The unemployment rate by regions indicator shows a very weak negative value of correlation in the Central Moravia and Southwest regions for the age group 15 to 24 . As for women in this age interval there was the same correlation in the Southwest region. As for men, there was a very weak negative correlation in the Central Bohemia region and weak negative correlation in the Central Moravia region at the age of 15-24 let. In the Northwest region there was a very weak negative correlation for the age 15 and older. A weak negative relation with the minimum wage showed the number of the unemployed in regional breakdown for the Central Moravia and Southwest regions at the age of 15-24. As for women, a very weak negative value of correlation was proved in Southwest and Central Moravia regions for women aged 15-24. As for men, there was a weak negative value of correlation in the Central Moravia region and a very weak negative correlation in Central Bohemia, Northeast and Southwest at the age of 15-24.

C. Unproven correlation, or no statistically significant impact of the year-on-year growth of the minimum wage in the Czech Republic was detected when analysing the unemployment rate of women according to the education attainment level, the indicator of the duration of

\footnotetext{
${ }^{1}$ Similar conclusions for both genders can be found in a study of the Department of Analysis and Information (Vláda České republiky, 2014).
} 
unemployment, long-term unemployment and the number of the unemployed according to the type of employment sought.

\section{Conclusion}

1. Having compared average values of the correlation coefficient of the year-on-year change of the minimum wage and unemployment, we can say that in Poland and Hungary there is a predominance of a moderately strong positive correlation (values 0.56 and 0.69 ). In Slovakia there was a predominance of the moderately strong negative correlation between the presented indicators (0.64). In the Czech Republic there was a weak positive value of this correlation (0.46). This proves that a rise of the minimum wage in Poland, Hungary and the Czech Republic would most probably lead to an increase of unemployment - just as Behrman et al. (1983) state in their study.

Wellington (1991) thinks that negative effects of the minimum wage are the same for all young employees, regardless of the race, national or gender group they belong to. In the case of Slovakia there was a positive value with a weak intensity found for a correlation coefficient between minimum wage and the unemployment rate of people aged 15-24. In the Czech Republic we proved a very weak negative correlation for women aged 50 to 64 . Similarly, Brown et al. (1983) and Kosters and Welch (1972) detected that an increase in the federal minimum wage led to a decrease of employment of young people at the age 16 to 19. In this context, the analysis suggested a weak positive dependence between the overall unemployment rate of men aged 15-19 and the minimum wage indicators in Poland.

Lianos (1972) confirmed there was an impact of the positive correlation of the minimum wage on employment in the agriculture sector in the south part of the USA. The estimate of labour force reduction as a result of minimum wage growth was significant. As for the Czech Republic, there was a very weak positive correlation found in relation to the number of the unemployed according to individual professions for women who used to work in the sector of services and trade. In Slovakia there was a weak positive correlation found for the unemployed in total and for men who used to work as craftsmen and related professions, and also for both genders if the unemployed used to work as machinists, machine operators or assemblers. As for men, there also was a weak positive correlation for the profession of a skilled worker. In Hungary there was a very weak positive correlation for farmers, foresters and fishermen with professional training.

Moore (1971) found that increasing minimum wage has a negative impact mainly on young nonwhite employees and that women aged 16 to 19 are affected more than men. In Slovakia there was a very weak positive correlation with the unemployment rate localised for men aged 20-24. Women at the age of 15 to 24 showed a weak positive correlation.

Manning (2012), who takes into account a higher minimum wage in London, as a common minimum wage there has a smaller impact on employment than outside large cities. For example in Slovakia, the correlation of minimum wage and the unemployment rate of people aged 15 and older, considered from the point of view of regions showed a very weak intensity in Central Slovakia, as opposed to a moderate intensity in Western Slovakia. In the Czech Republic, in the case of the women's unemployment rate at the age of 25 and older, there was a very weak positive correlation in the Northwest region, while in the Central Bohemia region there was a very weak negative correlation.

As opposed to other V4 countries, an increase of the minimum wage in Slovakia leads to a decrease of unemployment. This conclusion is in line with the estimations made by Brown et al. 
(1983) who found that in the USA an increase in the minimum wage has a significant impact on a decrease of the number of young unemployed people aged 20 to 24. In Slovakia this concerns the registered unemployment without benefits payment indicator, for which we found a moderately strong negative correlation for people aged 15-39.

2. The overall conclusion of the empirical analysis carried out with the use of correlation coefficient values indicates there is a predominance of the positive influence of the minimum wage on unemployment in the V4 countries. Slovakia was the only exception, as the year-on-year growth of the minimum wage led to greater chances of the unemployed to get back to the labour market. The intensity of the influence was moderately strong in Hungary, Slovakia and Poland and weak in the Czech Republic. Only a small number of statistically insignificant relations were found in the Czech Republic, Slovakia and Poland; in Hungary none were found.

\section{References}

Aksentievič, K. N., \& Bogovič, D. N. (2003). Economic inequality and the influence of salaries on income inequality in the Republic of Croatia. Zbornik Radova Ekonomskog Fakulteta U Rijeci-Prcoceedings of Rijeka Faculty of Economics, 21(1), 37-51.

Behrman, J. R., Sickles, R. C., \& Taubman, P. (1983). The impact of minimum wages on the distributions of earnings for major race-sex groups: a dynamic analysis. The American Economic Review, 73(4), 766-778.

Bell, N.F.D., \& Wright, R. E. (1996). The impact of minimum wages on the wages of the low paid: evidence from the Wage Boards and Councils. The Economic Journal, 106(436), 650-656. http://dx.doi.org/10.2307/2235572

Betcherman, G., Luinstra, A., \& Ogawa, M. (2001). Labor market regulation: international experience in promoting employment and social protection. World Bank, Social Protection Discussion Paper Series, 128, 9-12.

Blanchard, O., \& Wolfers, J. (1999) The Role of Shocks and Institutions in the Rise of European Unemployment: The Agregate Evidence. NBER Working Paper Series, No 7282.

Brezová, M., \& Pániková, L. (2011). Influence of minimum wage on labour market-case of Slovak Republic. Analytické centrum MPSVR SR, Bratislava.

Brown, C., Gilroy, C., \& Kohen, A. (1983). Time-Series Evidence of the Effect of the Minimum Wage on Youth Employment and Unemployment. The Journal of Human Resources, 18(1), 3-31. http://dx.doi.org/10.2307/145654

Butcher, T., Dickens, R., \& Manning, A. (2012). Minimum wages and wage inequality: some theory and an application to the UK. CEP Discussion Paper, No 1177.

Cazes, S., \& Nešporová, A. (2003). Labour markets in transition: balancing flexibility \& security in Central and Eastern Europe. Geneva: International Labour Organization.

Cazes, S., \& Nešporová, A. (2004). Labour markets in transition: balancing flexibility and security in Central and Eastern Europe. Revue de l'OFCE, (5), 23-54. http://dx.doi.org/10.3917/reof.075.0023

Cotterill, P. G., \& Wadycki, W. J. (1976). Teenagers and the Minimum Wage in Retail Trade. Journal of Human Resources, 69-85. http://dx.doi.org/10.2307/145074 
Čok, M., Domadenik, P., Redek, T., \& Verbic, M. (2009). Labour market reforms in the context of political power theory: The case of Slovenia. Zbornik Radova Ekonomskog Fakulteta u Rijeci-Prcoceedings of Rijeka Faculty of Economics, 27(1), 57-82.

Dube, A., Lester, T. W., \& Reich, M. (2010). Minimum wage effects across state borders: Estimates using contiguous counties. The review of economics and statistics, 92(4), 945-964. http://dx.doi.org/10.1162/REST_a_00039

Ederveen, S., \& Thissen, L. (2004). Can Labour Market Institutions Explain Unemployment Rates in New EU Member States?. CEPS ENEPRI Working Papers No. 27.

Eurostat. (2015). Database. Retrieved 2015, from http://ec.europa.eu/eurostat/data/database

Grossberg, A. J., \& Sicilian, P. (2004). Legal minimum wages and employment duration. Southern Economic Journal, 70(3), 631-645. http://dx.doi.org/10.2307/4135335

Hirsch, B. T., Kaufman, B. E., \& Zelenska, T. (2011). Minimum wage channels of adjustment. IZA DP, No. 6132. 32-34.

Jašová, E., Kadeřábková, B., Čermáková, K., \& Procházka, P. (2016). Influence of Institutional Factors on Structural and Cyclical Unemployment in the Countries of the Visegrad Group. Politická ekonomie, 65(1), 34-50. http://dx.doi.org/10.18267/j.polek.1053

Kertesi, G., \& Kollo, J. (2003). The employment effects of nearly doubling the minimum wage-the case of Hungary, Labour Research Department, Institute of Economics, Hungarian Academy of Sciences.

Kosters, M., \& Welch, F. (1972). The effects of minimum wages on the distribution of changes in aggregate employment. The American Economic Review, 62(3), 323-332.

Lianos, T. P. (1972). Impact of minimum wages upon the level and composition of agricultural employment. American Journal of Agricultural Economics, 54(3), 477-484. http://dx.doi.org/10.2307/1239164

Machin, S., \& Manning, A. (1994). The effects of minimum wages on wage dispersion and employment: Evidence from the UK Wages Councils. Industrial \& Labor Relations Review, 47(2), 319-329. http://dx.doi.org/10.1177/001979399404700210

Machin, S., \& Wilson, J. (2004). Minimum wages in a low-wage labour market: Care homes in the UK. The Economic Journal, 114(494), C102-C109. http://dx.doi.org/10.1111/j.0013-0133.2003.00199.x

Manning, A. (2012). Minimum Wage: maximum impact. Resolution Foundation.

Metcalf, D. (2007). Why has the British national minimum wage had little or no impact on employment?. CEP Discussion Paper No 781, 50-52. http://dx.doi.org/10.1177/0022185608090003

Moore, T. G. (1971). The effect of minimum wages on teenage unemployment rates. The Journal of Political Economy, 897-902. http://dx.doi.org/10.1086/259796

Neumark, D., \& Wascher, W. (2002). State-level estimates of minimum wage effects: new evidence and interpretations from disequilibrium methods. Journal of Human resources, 35-62. http://dx.doi.org/10.2307/3069603

Obadic, A., Šimurina, N., \& Sonora, R. J. (2014). The effects of tax policy and labour market institutions on income inequality. Zbornik Radova Ekonomskog Fakulteta u Rijeci-Prcoceedings of Rijeka Faculty of Economics, 32(1), 121-140. 
Orrenius, P. M., \& Závodný, M. (2008). The effect of minimum wages on immigrants' employment and earnings. Industrial \& Labor Relations Review, 61(4), 544-563. http://dx.doi.org/10.1177/001979390806100406

Vláda České republiky. (2014). Vliv minimální mzdy na nezaměstnanost v ČR. Retrieved 2015, from https://www.vlada.cz/cz/media-centrum/dulezite-dokumenty/vliv-minimalni-mzdy-na-nezamestnanostv-cr-122290/

Warren, J. R., \& Hamrock, C. (2010). The effect of minimum wage rates on high school completion. Social forces, 88(3), 1379-1392. http://dx.doi.org/10.1353/sof.0.0316

Wellington, A. J. (1991). Effects of the minimum wage on the employment status of youths: An update. Journal of Human Resources, 26(1), 27-46. http://dx.doi.org/10.2307/145715

Yuen, T. (2003). The Effect of Minimum Wages on Youth Employment in Canada A Panel Study. Journal of Human Resources, 38(3), 647-672. http://dx.doi.org/10.2307/1558771 